\title{
Kütüphanecilik ve Bilgibilim Araştırmalarının Alt Konu Alanlarına Dağılımı ve Alt Alanların Atıf Potansiyelleri Üzerine Bir Araştırma ${ }^{1}$
}

\author{
Zehra Taşkın²
}

Öz: Günümüzde araştırma performans değerlendirmeleri sıklıkla sayısal kriterlere dayanmaktadır. Ancak bu sayısal kriterler belirlenirken disiplinler ve bu disiplinlerin alt alanlarının özellikleri sıklıkla gözden kaçırılmaktadır. Tüm araştırmacıların/araştırma alanlarının eşit olduğu varsayımını da beraberinde getiren bu yaklaşım aynı disiplin içinde sayısal olarak avantajlı veya dezavantajlı araştırma alanlar yaratmaktadır. Bu çalışmanın temel amacl, Türkiye'de yürütülen kütüphanecilik ve bilgibilim araştırmalarının alt konu kategorilerini iki köklü kütüphanecilik dergisinde (Türk Kütüphaneciliği ve Bilgi Dünyası) yayımlanmış makalelere ilişkin veriler kullanılarak sosyal ă̆ analizi yöntemiyle belirlemek ve her bir alt alanın özelliklerini ortaya çıkarmaktır. Bu amaçla 520 araştırma makalesi ile bu makalelerin atıf yaptığ 16.750 kaynak detayll olarak incelenmiştir. Sosyal ăg analizini gerçekleştirmek üzere görselleştirme aracı olarak VOSviewer, istatistik yazllımı olarak ise $R$ Commander programından yararlanılmıştır. Araştırmanın bulgularına göre, Türkçe kütüphanecilik ve bilgibilim literatüründe dünya literatürüne paralel olarak dokuz farklı alt konuda araştırmalar yürütülmektedir. Alt konu kategorisi ile yayın için seçilen dergi arasında anlamlı bir ilişki bulunmaktadır. Bunun yanında yayın yapılan alt konu kategorisi ile yayının aldığı atıf sayısı arasında da ilişki saptanmıştır. Son olarak, alt konu kategorilerine göre atıf yapılan kaynak türlerinin farklılık gösterdiği anlaşılmıştır. Bu çalışmadan elde edilen sonuçlar yalnızca araştırma performans değerlendirmelerini iyileştirmeye yönelik olarak değil, kütüphanecilik ve bilgibilim alanında hizmet tasarlama aşamasında da kaynak olarak kullanılabilir.

Anahtar Sözcükler: Kütüphanecilik literatürü, bibliyometri, sosyal ă̆ analizi, atıf analizi, atı potansiyeli, VOSviewer.

\section{Giriş}

Araştırma performans değerlendirmeleri günümüzde kişi ve kurumların hesap verebilirliğini sağlamak, mevcut durumu anlamak ve analiz etmek, fon tahsisini anlamlı/yararlı hale getirmek veya fikir savunuculuğu yapmak için kullanılmaktadır (Guthrie, Wamae, Diepeveen, Wooding ve Grant, 2013, s. 1). Bu gibi değerlendirmelerde akranlara danışma, görüşme veya içerik analizleri gibi çeşitli yöntemler kullanılsa da en yaygın ve karar vericilerin en sık tercih ettikleri değerlendirmeler bibliyometrik ölçevler kullanılarak gerçekleştirilmektedir. Bunun temel sebebi sayılara dayalı değerlendirme yöntemlerinin, örneğin araştırma değerlendirmelerinde yayın sayısının bir ölçev olarak kullanılmasının oldukça kolay olmasıdır (Al, 2008, s. 32). Ancak, tamamıyla sayılara

\footnotetext{
${ }^{1} \mathrm{Bu}$ araştırma Hacettepe Üniversitesi Bilgi ve Belge Yönetimi Bölümü tarafından Prof. Dr. Nazan Uçak'a armağan niteliğinde hazırlanmakta olan "Bilgi Araştırmaları" başlıklı kitap için kaleme alınmış yazının yayın öncesi (pre-print) sürümüdür.

2 Adam Mickiewicz University, Scholarly Communication Research Group, Poznań, Poland
} 
dayanan performans değerlendirme sistemlerinde değerlendirilecek kişi, kurum veya ülkeler arasında karşılaştırma yaparken disiplinlerin kendine has özelliklerinin dikkate alınması gerektiği çeşitli çalışmalarla ortaya koyulmuştur (Archambault ve Gagné, 2004; Belter, 2015; Glänzel, Thijs, Schubert ve Debackere, 2008; Moed, Burger, Frankfort ve Van Raan, 1985; Uçak ve Al, 2009). Bunun temel sebebi, disiplinlerarası farklılıklar dikkate alınmaksızın yapılan performans değerlendirmelerinde yayın üretimi fazla ve dolayısıyla atıf sayısı da yüksek olan bazı disiplinlere avantaj sağlanması ve yayın üretimi az olan sosyal bilimler veya sanat gibi alanların araştırma değerlendirmelerinde yeterince temsil edilememesidir. Bunun önüne geçmek için her disipline özgü ve özelleştirilmiş ölçevlerin geliştirilmesi gerektiği çeşitli araştırma ve girişimlerle ortaya koyulmaktadır (ENRESSH, 2019; Wilson ve diğerleri, 2015).

Öte yandan y1llar içinde bibliyometrik yöntemlerin gelişmesi ve sosyal ağ analizinin de alanların yapılarının anlaşılmasına yönelik olarak kullanılmaya başlanması ile birlikte aynı disiplin içinde çalışılan alt alanların da farklı özellikler gösterebileceği ortaya koyulmakta ve disiplinler mikro düzeyde incelenmektedir (Ör. van der Zee ve Vanneste, 2015; Zhu ve Yan, 2015). Kütüphanecilik ve bilgibilim alanında da bu gibi çalışmalar yer bulmuştur. Örneğin, kütüphanecilik ve bilgibilim alanının detaylı değerlendirmesini bir derleme yazısı ile ortaya koyan Hjørland (2018), literatürde yer alan çalışmaları kütüphane bilimi, bilgi bilimi ve dokümantasyon olarak üç gruba ayırmış, her bir alanı da içerdiği alt konulara göre sınıflamıştır. Kütüphane ve Bilgibilim Ansiklopedisinde (Encyclopedia of Library and Information Science) ise ilgili alan uzmanlık alanlarına göre arşiv bilimleri, enformatik, bilgi bilimi, kütüphane ve bilgi bilimi, müze çalışmaları, yayıncılık, bibliyografi ve üslup analizi ile belge yönetimi olarak yedi gruba ayrılmıştır (Bates ve Maack, 2009). Öte yandan araştırma alanlarına göre ise bibliyometri, bilgi davranışları ve bilgi arama, bilginin organizasyonu, bilgi erişim, bilgi sistemleri tasarımı, yasal ve etik konular, sosyal yaşam ve kültürel kayıtlar, sosyal ilişkiler ve bilgi teknolojileri ve bilginin sosyal çalışmaları olarak dokuz temel sınıf belirlenmiştir. Literatürde bu alan üzerine yürütülen sosyal ağ analizi çalışmalarında ise sıklıkla karşılaşılan alt alanlar kütüphane bilimi, bilgi erişim ve bibliyometri olmuştur (Åström, 2002, s. 190; van Eck ve Waltman, 2011). Türkiye'deki kütüphanecilik ve bilgibilim çalışmalarını alt konu başlıklarına göre analiz eden ve dünya ile karşılaştırmasını yapan bir çalışmada Türkiye'de yayımlanan makalelerin dünya ile paralel olarak benzer konulara sahip olduğu, ancak buna ek olarak belge yönetimi konusunun da önemli bir yeri bulunduğu sonucuna ulaşılmıştır (Taşkın, Doğan ve Al, 2016). Türkçe kütüphanecilik ve bilgibilim literatürü üzerine kaleme alınan bir diğer görselleştirme çalışmasında da temel tematik kümelerin üniversite kütüphaneleri, okuma alışkanlığı, halk kütüphaneleri, Türk Kütüphaneciliği dergisi, bilimsel iletişim, açık erişim, atıf analizi, bibliyometri, arşivcilik, elektronik yayıncılık, belge sağlama, bilgi okuryazarlığı, internet, bilgi yönetimi, dijital kütüphaneler, belge yönetimi, bilgi arama davranışları olduğu saptanmıştır (Polat, Akkaya ve Binici, 2016, s. 671). Literatürde yürütülen tüm bu çalışmalardan hareketle disiplinler ve çalışma alanlarının derinlemesine incelenmesi ve yapılarının ortaya koyulması ile araştırma performans değerlendirmelerinin daha etkin hale gelebileceğini söylemek yanlış olmayacaktır. Bunun yanında bu analizler aracılığı ile ilgili konu alanlarında çalışan kişilerin bilgi ihtiyaçları ve bilgi kullanım özellikleri detaylı olarak anlaşılabileceğinden ilgili gruplara hizmet tasarımının kolaylaşacağı düşünülmektedir. 
Literatürde yer bulmuş yukarıda sıralanan çalışmalardan hareketle bu yazının temel amacı, kütüphanecilik ve bilgibilim literatüründe yapılan yayınların alt konu kategorilerine dağılımının sosyal ağ analizi yöntemiyle ortaya koyulması ve her bir alt alanın özelliklerinin tanımlanmasıdır. Bu bağlamda, sosyal ă̆ analizi yöntemiyle belirlenen alt alanların kaynak kullanma ve atıf alma potansiyelleri araştırılmıştır. Çalışma kapsamında yanıt aranan temel araştırma soruları aşağıda sıralandığı gibidir:

- Kütüphanecilik literatüründe yapılan araştırmaların alt konu kategorilerine dağılımı nasıldır? Alt konular arasında yakınsama söz konusu mudur?

- Kütüphanecilik ve bilgibilim disiplininin alt alanlarında yayımlanan makaleler için seçilen dergiler konularına göre farklılık göstermekte midir?

- Kütüphanecilik ve bilgibilim alanında yayın yapılan alt alanlar ile alınan atıf sayısı arasında anlamlı bir farklılık var mıdır? Alınan atıf sayısı yayın yapılan alana göre değişiklik göstermekte midir?

- Kütüphanecilik ve bilgibilim alanının alt çalışma alanlarının atıf yaptıkları kaynak türleri (tez, rapor, makale gibi) arasında anlamlı bir farklılık var mıdır?

Araştırma sorularına yanıt verebilmek amacı ile Türkiye kütüphanecilik ve bilgibilim literatürünün köklü iki dergisinde (Türk Kütüphaneciliği ve Bilgi Dünyası) yayımlanmış makaleler incelenmiş ve elde edilen sonuçlar sunulmuştur.

\section{Yöntem}

Araştırma sorularına yanıt bulmak amacıyla Türkçe kütüphanecilik ve bilgibilim literatürünün köklü iki dergisi olan Türk Kütüphaneciliği (1996³-2018) ve Bilgi Dünyası $\left(2000^{4}\right.$-2018) dergilerinde yayımlanmıs hakemli makaleler değerlendirme kapsamına alınmıştır. Çalışmanın en önemli sınırlılı̆̆ tüm disiplini temsil etmesi için yalnızca iki derginin seçilmiş olmasıdır. Ancak uzun yıllardır yayın hayatına devam eden bu iki derginin ulusal literatürün çekirdek dergileri olduğu pek çok çalışmada dile getirilmiştir (örneğin, Atılgan, Atakan ve Bulut, 2008, s. 397; Bitri ve Keseroğlu, 2015, s. 241; Uçak, 2008, s. 31). Bu sebeple bu iki derginin Türkçe kütüphanecilik ve bilgibilim literatürünün konusal çerçevesini çizmede yeterli olduğu düşünülmektedir.

İlk aşamada belirtilen yıllar arasında yayımlanmış 520 hakemli makaleye ilişkin tüm üst veriler toplanmıştır. Kayıt altına alınan veriler makale başlıkları, özleri ve anahtar sözcükleri (Türkçe ve İngilizce) ile yazar / kurum adı bilgileridir. Yazar ve kurum adları tutarlılığı sağlamak amacıyla ilk aşamada standartlaştırılmıştır. Veri seti içinde her bir makalenin ayırt ediciliğini sağlamak amacıyla bir makale_ID alanı oluşturulmuştur. Bu akıllı numara makalenin yayımlandığı dergi, yayın yılı ve cilt bilgilerini içermektedir.

\footnotetext{
${ }^{3}$ Türk Kütüphaneciliği dergisi hakemli dergi statüsüne geçtiğini 1995 yılı ilk sayısında duyurmuştur (Tonta, 1995, s. 3). Çalışma kapsamına yalnızca hakemli makaleler dahil edildiğinden tüm sayıları hakem değerlendirmesinden geçmiş olan 1996 yılı ve sonrası hakemli makaleler çalışma kapsamına dahil edilmiştir.

${ }^{4}$ Bilgi Dünyası dergisi 2000 yılında hakemli bir dergi olarak kurulduğundan başlangıçtan itibaren yayımlanmış tüm hakemli makaleler değerlendirme kapsamına alınmıştır.
} 
Örneğin, BD200827 numarasının tanımlandığı makale Bilgi Dünyası dergisinde 2008 yılının ikinci sayısında yayımlanmış yedinci makaleyi temsil etmektedir.

$\mathrm{Bu}$ işlemin ardından her bir makalenin atıf yaptığı kaynaklar ayrı bir tablo ile veri setine eklenmiştir. Bu tabloda makale_ID, atıf_ID, atıf yapılan kaynağın künyesi ile atıf yapılan kaynak türüne ilişkin bilgi tutulmuştur. Bu tabloda 520 makaleye ait 16.570 kaynakça bilgisi yer almıştır. Atıf yapılan kaynaklar dergi makalesi, kitap, kitap içi bölüm, ekaynak, standart, yasa/yönetmelik, rapor, tez, bildiri ve diğer (arşivsel materyal, haber, eposta vb.) sınıflarına ayrılmıştır. Bu tablodan hesaplanan her bir yayının kaynakçasında yer alan kaynak sayısı tekil numara aracılığıyla ana tabloya aktarılmıştır.

Ana tabloya referans sayılarının yanı sıra, çalışmaların aldıkları atıf sayıları da eklenmiştir. Her iki dergi de atıf dizinlerinde (WoS veya Scopus gibi) belirli bir yıldan sonra yer bulduğundan ve her iki dergide yayımlanan makalelerin içerikleri çoğunlukla yerel/bölgesel olduğundan tüm atıfları analize dâhil edebilmek amacıyla atıf veri kaynağı olarak Google Scholar kullanılmıştır. Atıf sayılarına ulaşmak için makale başlıkları kullanılmış ve taramalar 20 Nisan 2019 tarihinde gerçekleştirilmiştir. Yazarların aynı başlıklı başka yayınları olması durumunda (teze dayanan makale gibi) yalnızca makaleye yapılan atıflar sonuçlar içinden filtrelenerek değerlendirme kapsamına alınmıştır.

Çalışma kapsamında Türkiye'de yayımlanmış kütüphanecilik ve bilgibilim çalışmalarının konusal alt alanlarını ortaya çıkarmak amacıyla sosyal ă̆ analizi yapılmıştır. Sosyal yapıları ortaya çıkarmak üzere geliştirilen sosyal ağ analizi, kütüphanecilik ve bilgibilim alanında yayın, atıf, ortak atıf, yazar/kurum/ülke işbirliklerinin yapısı gibi sosyal etkileşim ağlarını incelemek üzere kullanılmaktadır (Otte ve Rousseau, 2002, s. 441). Sosyal ağ analizini gerçekleştirmek üzere İngilizce başlık, özet ve anahtar sözcükler kullanılmıştır. Bunun temel sebebi, ağ görselleştirmesi için kullanılan yazılımın İngilizceyi destekliyor oluşudur. Öte yandan görselleştirme yapılmadan önce anahtar sözcük tekilleştirmesi yapılarak anahtar sözcük haritalarının daha tutarlı olması sağlanmıştır. Bu işlemde;

- Çoğul eki almış sözcükler (children, librarians, libraries gibi) tekilleştirilmiştir.

- Sözcüklerin farklı varyasyonları (behaviour, behavior, organisation, organization gibi) saptanmış ve tekilleştirilmiştir.

- Kısaltmalar ve açık versiyonları (IoT ve internet of things gibi) tekilleştirilmiştir.

- Eş anlamlı sözcükler tekilleştirilmiştir.

- İsim tamlamaları ve birleşik isimler saptanmıştır.

Tekilleştirme işleminin ardından ağ görselleştirmesi amacıyla VOSviewer ${ }^{5}$ yazılımı kullanılmıştır. Java altyapısını kullanan açık kaynak kodlu VOSviewer yazılımı bibliyometrik ağların ortaya koyulması için sıklıkla kullanılan araçlardan biridir. Yazılımın kullanımı ile ilgili tüm detaylar "VOSviewer El Kitabı"nda sunulmaktadır (van Eck ve Waltman, 2019). Öte yandan sosyal ă analizinde ağın detaylı olarak görüntülenebilmesini sağlamak üzere etkileşimli harita bağlantısı görsel etiketine

\footnotetext{
${ }^{5}$ http://www.vosviewer.com/
} 
eklenmiştir. Bu bağlantı aracıllğıyla ağdaki ilişkilerin detaylı olarak izlenmesi mümkün olabilmektedir. ${ }^{6}$

Atıf sayıları normal dağılım göstermediği için, atıf sayıları ile alt alanlar arasında anlamlı ilişki olup olmadığını saptamak üzere Kruskal Wallis testi, hangi sınıflar arasında anlamlı farklılık olduğunu ortaya çıkarmak üzere ise sınıflar arasında Mann Whitney U testi uygulanmıştır. Yayının yer aldığı dergi ile konu kategorisi arasındaki ilişki ve atıf yapılan kaynakların türü ile alt konu alanı arasındaki ilişkinin saptanması için ise ki-kare testinden yararlanılmıştır. Sınıfların ortalama ve ortanca atıf sayıları, çeyrek sapma değerleri ve dağılım genişlikleri kutu grafiği (box-plot) aracılığı ile sunulmuştur. Testlerin uygulanması ve grafiklerin hazırlanması için açık kaynak kodlu bir yazılım olan ve $\mathrm{R}$ altyapısıyla çalışan R-Commander ${ }^{7}$ ve KMggplot2 eklentisi kullanılmıştır. Tüm test sonuçları bulgular bölümünde detaylı olarak sunulmakta ve yorumlanmaktadır.

\section{Bulgular}

\section{Tanımlayıcı Ístatistikler}

1996 ile 2018 yılları arasında Türkiye'de kütüphanecilik ve bilgibilim alanının önde gelen iki dergisinde toplam 520 araştırma makalesi yayımlanmıştır (Türk Kütüphaneciliği: 299, Bilgi Dünyası: 221). Bu yayınlarda yayın başına ortalama 32 kaynağa atıf yapılmıştır. Türk Kütüphaneciliği dergisinde yıllık ortalama 14 makale yayımlanırken Bilgi Dünyası dergisinde bu sayı $12^{\prime}$ 'dir. Her iki dergide yayımlanan makaleler ve bu yayınlarda kullanılan kaynakların sayısı ile, ilgili yayınların aldıkları atıfların yıllara göre dağılımı Şekil 1'de sunulmaktadır. Birinci eksen yayın sayısını, ikinci eksen ise atıf ve kaynak sayılarını temsil etmektedir. Şekil 1'den de görüldüğü üzere kütüphanecilik ve bilgibilim alanında en fazla makalenin yayımlandığı yıllar 2012 ve 2013 yıllarıdır. Yıllar içinde yayınlar daha fazla kaynağa atıf yapmakta, ancak alınan atıf sayıları benzer bir hızla artmamaktadır. Şekil 2 ve Şekil 3'te kaynak ve atıf sayıları daha derinlemesine incelenmektedir.

Türk Kütüphaneciliği dergisinde yayımlanmış makalelerin kaynakçalarında ortalama olarak 31,5 kaynağa atıf yapılırken; Bilgi Dünyası dergisinde bu sayı 32,3'tür. Şekil 2'de sunulan kutu grafiğinde her iki dergide yayımlanan makalelerin atıf yaptıkları kaynakların dağılımına ilişkin minimum ve maksimum değerler ile ortanca değerleri sunulmaktadır. Şekle göre kaynakça bölümünde atıf yapılan yayın sayılarının yıllar içinde artı̧̧ yönünde değişiklik gösterdiği izlenmektedir, yani alandaki yayın sayısının artışına paralel olarak kullanılan kaynak sayısı da artış göstermiştir. Öte yandan son iki yıldaki azalmanın sebebi de ilgili iki yılda dergilerde yayımlanan makale sayısında görülen azalmadir.

\footnotetext{
${ }^{6}$ Etkileşimli bağlantı aracılığı ile indirilen .jnlp dosyasının çalıştırılabilmesi için ilgili bilgisayarlarda güncel Java programının yüklü olması gereklidir.

${ }^{7}$ https://www.rcommander.com/
} 




Şekil 1. Kütüphanecilik ve bilgibilim alanında yayımlanan makaleler ve bu makalelerin aldıkları atıflar ile kullandıkları kaynak sayılarının yıllara göre dağılımı

Akademik performans değerlendirme sistemlerinin bilimsel çıktı sayısını artırmayı hedefleyen yapısı nedeni ile üretilen yayınların sayılarının artışı ve buna paralel olarak kullanılan kaynakların da artıyor oluşu önemli bir problemi de beraberinde getirmektedir. Pek çok yazarın atıf yaptığı kaynağı okumadığı (Simkin ve Roychowdhury, 2003, s. 269), hatta yayımlanan araştırma makalelerinin yarısının yazarları, editörleri veya hakemleri dışında kimse tarafından okunmadığı bildirilmektedir (Tripathy ve Tripathy, 2017, s. 198). Bu bağlamda ülkemizde kütüphanecilik ve bilgibilim alanında yapılan atıfların daha detaylı incelenmesi önemlidir. Bunun da yalnızca alınan atıflar çerçevesinde değerlendirilmesi doğru olmayacaktır. Kullanılan kaynakların incelenmesi alanımızın temel özelliklerinin belirlenebilmesi açısından büyük önem taşımaktadır.

Bir çalışmada (Taşkın, 2018, s. 346) ülkemizde yayımlanan kütüphanecilik ve bilgibilim araştırmalarında yapılan atıfların \%97'sinin nötr atıflar olduğu ve \%84'ünün ise literatür değerlendirmesi amacı ile yapıldığı sonucuna ulaşılmıştır. Bu bulgunun devamı olarak nitel bir araştırma yürütülerek bu alanda çalışan yazarların atıf yapma motivasyonlarının anlaşılabilmesi önemlidir. Zira, bir çalışmaya göre (Fox ve diğerleri, 2016, s. 7720) daha çok kaynak kullanan çalışmaların atıf alma potansiyellerinin daha yüksek olduğu ortaya çıkarılmıştır. Yazarların daha fazla kaynak kullanmak istiyor olma sebebi daha fazla atıf alma arzusu olabilir. Bununla birlikte Matthew etkisi de atıf sayısını belirleyen etmenlerden biridir (Merton, 1968). Bir atıf almış yazarın gelecekte atıf alma ihtimali hiç atıf almamış bir yazara göre daha fazla olacaktır. Yazarların atıf yapma motivasyonlarının ve atıf örüntülerinin anlaşılması ile atıfların araştırma değerlendirmesindeki önemi konusunda daha anlamlı çıkarımlar yapmak mümkün olabilecektir.

Öte yandan iki dergi arasındaki kaynak kullanım sayısı bazı yıllarda benzerlik gösterse de sıklıkla çarpık bir yapı göze çarpmaktadır. Son iki yılda özellikle Türk Kütüphaneciliği dergisinde yapılan yayınlarda kaynak kullanımının azaldığ 1 görülmektedir. 22 yıllık döneme bakıldığında 100'den fazla kaynağa atıf yapan dört makale bulunmaktadır (bkz. Şekil 2). Bu makalelerin tamamı Türk Kütüphaneciliği dergisinde yayımlanmıştır. En çok kaynağa atıf yapan yayın 2009 yılında Mehmet Toplu tarafindan kaleme alınan "Mesleki Bir Örgüt Olarak Türk Kütüphaneciler Derneği’nin Altmış Yıllık Gelişim Çizgisi”" başlıklı makaledir. Çalışmada 131 kaynağa atıf yapılmıştır. Dört yayında ise hiç kaynak kullanılmamıştır. Bu çalışmaların tamamı da Türk Kütüphaneciliği'nde yayımlanmıştır. 


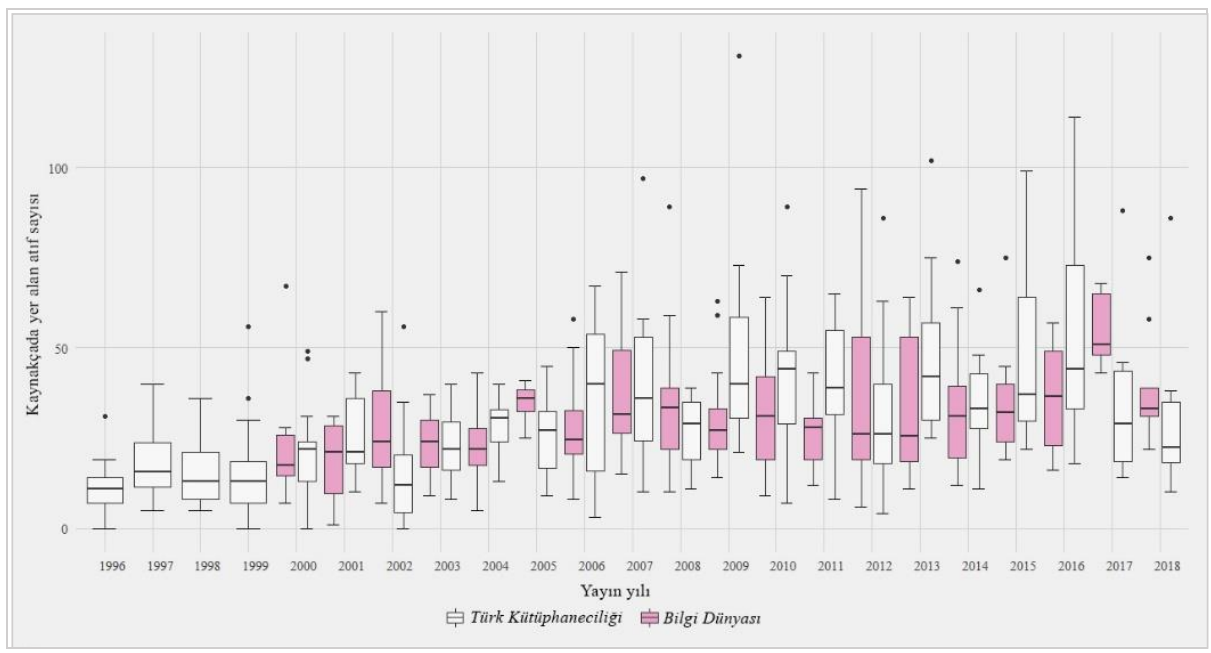

Şekil 2. Türk Kütüphaneciliği ve Bilgi Dünyası dergilerinde yayımlanan makalelerin atıf yaptı̆̆

Makalelerin aldıkları atıfların dağılımına bakıldığında ise Şekil 3'te sunulan kutu grafiği elde edilmiştir. Türkiye'de yayımlanan kütüphanecilik ve bilgibilim makaleleri toplam 5398 atıf almıştır. Bu atıfların \%62'sini Türk Kütüphaneciliği dergisinde yayımlanan makaleler almıştır. Türk Kütüphaneciliği dergisinde yayımlanan makalelerin ortalama atıf sayısı 11,2 iken; Bilgi Dünyası dergisi için bu sayı 9,2'dir. En çok atıf alan yayın 2008 yılında Bilgi Dünyası dergisinde yayımlanan "Üniversite Öğrencilerinin Okuma Alışkanlığı: Ankara Üniversitesi Örneği”" başlıklı makaledir. İlgili makale 196 atıf almıştır.



Şekil 3. Türk Kütüphaneciliği ve Bilgi Dünyası dergilerinde yayımlanan makalelerin aldıkları atıfların dağılımı 
100 ve üzeri atıf alan dört yayın bulunmaktadır. ${ }^{8}$ Bu yayınlardan ikisi Türk Kütüphaneciliği, diğer ikisi ise Bilgi Dünyası dergilerinde yayımlanmıştır. 95 yayın ise (\%18) henüz hiç atıf almamıştır. Hiç atıf almayan yayınların \%55'i Bilgi Dünyası'nda; \%45'i ise Türk Kütüphaneciliği'nde yayımlanmıștır. Atıf almayan yayınların yarısı son beş yılda yayımlanmıştır. Atıfların ortalama, ortanca ve tepe değerlerine bakıldığında çarpık bir yapıda olduğu izlenmektedir. Atıfların alt alanlara dağılımı incelendiğinde bu bulguya yönelik daha detaylı yorum yapmak mümkün olabilecektir.

\section{Sosyal A $\breve{g}$ Analizi ile Alt Alanların Saptanması}

Türkiye'de yayımlanan kütüphanecilik ve bilgibilim konulu 520 makalenin İngilizce başlık, özet ve anahtar sözcükleri kullanılarak oluşturulan ağ haritası Şekil 4'te gösterildiği gibidir.

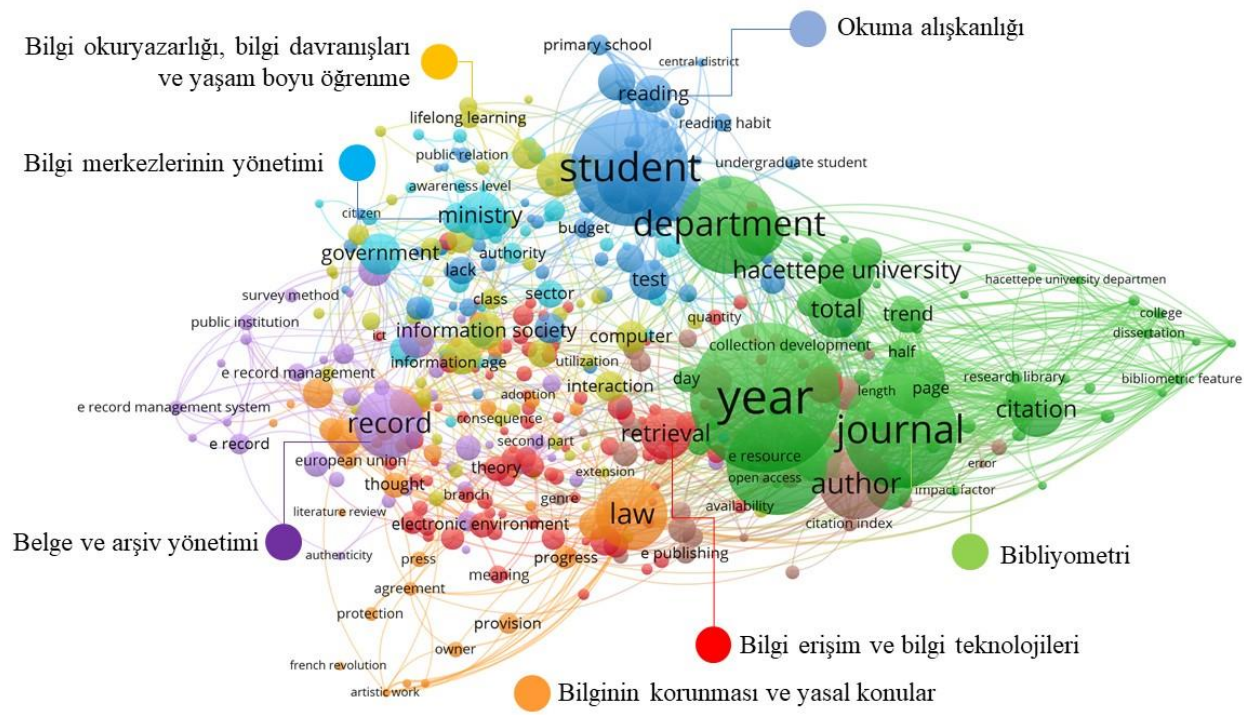

Şekil 4. Kütüphanecilik ve bilgibilim literatüründe yapılan çalışmaların konusal dağılımını gösteren ağ haritası (etkileşimli harita için: https://bit.ly/2vw8JjH)

Şekil 4'e göre Türkiye'de yürütülen kütüphanecilik ve bilgibilim çalışmalarında sekiz temel konu kümesinde yayın yapıldığı görülmektedir. Her bir küme detaylı olarak incelendiğinde çalışılan alanların kapsamlarını derinlemesine incelemek mümkün olmaktadır.

\footnotetext{
${ }^{8}$ En çok atıf alan dört yayın sırasıyla: 1 . Üniversite Öğrencilerinin Okuma Alışkanlığı: Ankara Üniversitesi Örneği - 196 atıf / 2. Öğrencilerin Televizyon İzlemeleri ve Bilgisayar Kullanmalarının Okuma Alışkanlıkları Üzerine Etkisi - 164 atıf / 3. Öz-Yeterlik İnancı ve Bilgi Profesyonelleri İçin Önemi - 115 atıf / 4. Dijital Yerliler, Sosyal Ağlar ve Kütüphanelerin Geleceği - 108 atıf
} 
İlk küme VOSviewer tarafından kırmızı renk ile belirlenen ve bilgi erişim/bilgi teknolojileri konusunda anahtar sözcükleri içeren kümedir. Bu kümenin en sık kullanılan anahtar sözcüklerinden bazıları erişim, elektronik ortam ve elektronik yayıncılık olarak belirlenmiştir.

İkinci küme ise sıklıkla bibliyometrik çalışmalar ile atıf analizi çalışmalarının yer aldığı yeşil kümedir. Bu kümenin en çok yakınsadığı küme kahverengi ile temsil edilen yayıncılık kümesidir. Kümede bibliyometrinin temel araştırma konularından olan yayın, atıf, dergi, bibliyometrik özellikler, yarı yaşam ve çekirdek dergi gibi sözcüklerin izlenmesi mümkündür.

Üçüncü küme ise mavi renkle temsil edilen okuma alışkanlığı kümesidir. Okul öncesi çocuklarının, öğrencilerin, öğretmenlerinin ve ebeveynlerin okuma alışkanlıklarının araştırıldığı çalışmalarla oluşan bu kümede, ögrenci, alışkanlık ve okuma alışkanlığ gibi sözcükler göze çarpmaktadır.

Dördüncü küme bilgi okuryazarlığı, bilgi davranışları ve yaşam boyu öğrenme konularında yapılan çalışmalarla oluşmuş sarı kümedir. Bu kümenin göze çarpan sözcüklerinden bazıları bilgi toplumu, bilgi okuryazarllğl, bilgi okuryazarllğı becerileri, yenilik ve sosyal gelişim sözcükleridir. Sarı kümenin kırmızı kümeye yakınsayan kısımlarında kişilerin bilgi sistemlerini kullanma becerileri ve davranışlarının işlendiği çalışmalarda kullanılan anahtar sözcükleri (bilgisayar, etkileşim uyum gibi) görmek mümkündür.

Mor renkle temsil edilen beşinci küme belge yönetimi, belge yönetim sistemleri ve arşiv yönetimi konularını kapsayan kümedir. Kümenin öne çıkan sözcükleri belge, belge yönetim uygulamaları, e-belge yönetimi, e-belge yönetim sistemleri, e-imza ve kamu kuruluşlarıdır.

Kütüphane ve bilgi merkezlerinin yönetimi konularında yapılan çalışmalarda kullanılan anahtar sözcükler ile turkuaz küme oluşmuştur. Bu kümenin sıklıkla halk ve belediye kütüphaneleri üzerine yapılan çalışmalar aracılığıyla oluştuğu söylenebilir. Kümenin öne çıkan sözcükleri yönetim, bakanlık, halk kütüphanesi ve halk kütüphanesi hizmetleri gibi sözcüklerdir.

Bilginin yasalarla korunması ve saklanması konusunda yapılan çalışmalar ise turuncu kümeyi oluşturmuştur. Yasalar, yönetmelikler, yasal düzenlemeler, telif haklarl, düşünce özgürlüğ̈̈ ve sansür gibi anahtar sözcükleri içeren bu kümenin tüm kümelerle bağlantısı olduğunu görmek mümkündür.

Son küme ise kahverengi ile temsil edilen yayıncılık kümesidir. Bu kümenin bibliyometri ile bilgi sistemleri kümesi arasında bağlantı niteliğine sahip olduğu düşünülebilir. Kümenin en belirgin sözcükleri e-yaylncıllk, açık erişim ve bilimsel yayıncılık gibi anahtar sözcüklerdir. 


\section{Kütüphanecilik ve Bilgibilim Alanının Alt Konu Başlıklarına İlişkin Analizler}

Çalışma kapsamında kütüphanecilik ve bilgibilim alanında Türkiye'de yapılan çalışmaların temel konu alanları belirlenmiştir. Bu konu alanları kullanılarak veri setinde yer alan tüm yayınlar en ilgili tek bir konu alanına dahil edilecek şekilde sınıflanmıştır. $\mathrm{Bu}$ sayede sosyal ağ analizinde saptanamayan bazı konu alanlarının da saptanabilmesi mümkün olmuştur. Etiketleme işleminin ardından Türkiye'de yayımlanan kütüphanecilik konulu çalışmalar dokuz temel kümeye ayrılmıştır. Bu ayrım yapılırken birbirine çok benzeyen bibliyometri ve yayıncılık kümesi birleştirilmiştir. Öte yandan sosyal ağ haritasında görüntülenmeyen ancak yayın yapılan iki konu (bilgi profesyonellerinin eğitimi ve kavramsal çalışmalar) sınıflamaya dâhil edilmiştir. Konusal alt kategorilerin belirlenmesinin ardından veri setinde yer alan her bir makale yalnızca bir alt konuya girecek şekilde sınıflandırılmıştır. Sınıflamanın ardından her bir alt konu kategorisinde yer alan yayınlara ilişkin detaylar aşağıda sıralanmaktadır:

- Belge yönetimi, arşivler, dijitalleştirme ve standartlar: İlgili konu kategorisinde toplam 98 yayın yapılmıştır. Bu yayınların 53'ü Bilgi Dünyası, 45'i Türk Kütüphaneciliği’nde yayımlanmıştır. İlgili 98 yayın konusal olarak detaylı incelendiğinde ${ }^{9}$ kamu kurumlarında ve üniversitelerde belge yönetimi uygulamaları, arşivler ve arşivsel ürünlere erişim, kurumsal belleğin yönetimi ve dijital insani bilimler, belge yönetiminde içerik analizi konuları ile dijital kültür, dijital kütüphane, standartlar ve bulut bilişimi içeren araştırma konularının sıklıkla çalışıldığı görülmektedir.

- Bibliyometri, istatistiksel analizler ve yayıncılık: Bu konu kategorisinde 95 yayın bulunmaktadır. Yayınların 63'ü Türk Kütüphaneciliği, geri kalanı ise Bilgi Dünyası'nda yer bulmuştur. Yayınlar incelendiğinde ${ }^{10}$ bu alanda yayımlanan çalışmaların tezlerin içerik analizi ve bibliyometrik açılardan değerlendirilmesi, konusal analizler, üniversite kütüphanelerinde koleksiyon yönetimi, açık erişim ve araştırma verilerinin yönetimi, bilgi kaynaklarının etkin kullanımı ve bilimsel iletişim konularında yapıldığını söylemek mümkündür.

- Bilgi okuryazarlığı ve bilgi davranışları: Bu konuda 68 yayın yapılmıştır. Yayınların yarısı Türk Kütüphaneciliği diğer yarısı ise Bilgi Dünyası dergisinde yayımlanmıştır. Konu alanı detaylı incelendiğinde ${ }^{11}$ bu kümede yapılan çalışmaların bilgi davranışları, kütüphane kaygısı, göçmenler üzerine yapılan çalışmalar, bilgi hizmetlerinin erişilebilirliği ve bilgi toplumu gibi konulara odaklandığı görülmektedir.

- Bilgi profesyonellerinin eğitimi: İlgili konuda yapılan yayın sayısı 12'dir. Bu yayınların büyük çoğunluğu (\%83) Türk Kütüphaneciliği'nde yayımlanmıştır. Bu alanda yayın sayısı az olduğu için ağ haritası oluşturulamasa da çalışmaların sıklıkla Türkiye'de kütüphanecilik ve bilgibilim eğitiminin iyileştirilmesine yönelik olarak yapıldığını söylemek mümkündür.

- Bilgi sistemleri, teknolojileri ve bilgi erişim: Bu konuda kütüphanecilik ve bilgibilim literatüründe 75 yayın yapılmıştır. İlgili yayınların \%57'si Türk

\footnotetext{
${ }^{9}$ Alt alanın haritası için: https://bit.ly/2WHGX21

${ }^{10}$ Alt alanın haritası için: https://bit.ly/2WMYAxD

${ }^{11}$ Alt alanın haritası için: https://bit.ly/2LGd23V
} 
Kütüphaneciliği dergisinde yer bulmuştur. Yayınlar detaylı incelendiğinde ${ }^{12}$ bu alanda yapılan çalışmaların web sitesi kullanılabilirlik değerlendirmeleri, eöğrenme araçları, kavramsal analizler, içerik standartları, anlamsal ă̆, bilgi merkezleri için yazılım seçimi ve arama motorları gibi konuları kapsadığı saptanmıştır.

- Etik, sansür, yasal konular ve bilgi politikaları: İlgili konuda 47 yayın yapılmıştır. Bu makalelerin \%60'ı Bilgi Dünyası dergisinde yayımlanmıştır. Makalelerin konusal dağılımı incelendiğinde ${ }^{13}$ bu alanda yapılan çalışmaların ulusal bilgi politikaları ve hareket planları, kütüphanelerin bu planlarda yeri, yasalarla korunan haklar (telif hakları vb.), kişisel verilerin korunması, düşünce özgürlüğü, intihal algısı ve bilgi ekonomisi gibi konuları içerdiği görülmüştür.

- Kavramsal ve tarihsel çalışmalar ile eleştiriler: Kütüphanecilik literatüründe 25 kavramsal ve tarihsel çalışma yer bulmuştur. Bu çalışmaların \%84'ü Türk Kütüphaneciliği dergisinde yayımlanmıştır. Yayın sayısı az olduğu için ă̆ haritası çıkmayan bu alanda yapılan çalışmaların sıklıkla mesleki tarihsel gelişmeler ve bu gelişmelere ilişkin getirilen eleştiriler ile temel kavramların açıklanması konularını içerdiği saptanmıştır.

- Kütüphaneler ve kütüphane türleri üzerine yapılan çalışmalar: İlgili konuda kütüphanecilik literatüründe yapılmış 80 hakemli makale bulunmaktadır. $\mathrm{Bu} 80$ makalenin \%66'sı Türk Kütüphaneciliği'nde yayımlanmıştır. Bu alanda yapılan çalışmalar detaylı incelendiğinde ${ }^{14}$ çalışmaların halk kütüphaneleri, hizmet tasarımı, kütüphane personelinin eğitimi, okul kütüphaneleri, iş birliği firsatları, toplam kalite yönetimi, kullanıcı memnuniyeti, müzeler ve kullanıcı analizlerine yoğunlaştığı görülmüştür.

- Okuma alışkanlığı: Kütüphanecilik ve bilgibilim literatüründe bu konuda yapılmış 20 yayın bulunmaktadır. $\mathrm{Bu}$ makalelerin \%55'i Türk Kütüphaneciliği'nde yayımlanmıştır. Yayın sayısının azlığından dolayı ăg haritası çıkarılamıyor olsa da bu alanda yapılan yayınların sıklıkla okul öncesi ve okul çocukları ile öğretmen ve ebeveynlerin okuma alışkanlıklarının araştırıldığı çalışmalar olduğunu söylemek mümkündür.

Kütüphanecilik ve bilgibilim alanında yapılan çalışmalarda yazarların, makalelerinin konusuna göre dergi seçip seçmedikleri araştırıldığında makalenin yayımlandığı dergi ile alt konu kategorisi arasında anlamlı bir ilişki olduğu sonucuna ulaşılmıştır $\left(\chi_{(4)}^{2}=28,592\right.$, $p=0,000)$. Bu bulgu da, Türkçe literatürde yayın yapan araştırmacıların makalelerinin konularına göre dergi seçtikleri olarak yorumlanabilir.

\section{Alt Konu Kategorilerinin Atıf Performanslarının Değerlendirilmesi}

Çalışma kapsamında her bir alt alanın atıf örüntüleri ortaya çıkarılmış, bu sayede alt alanların atıf performansı açısından benzerlik ve farklılıkları saptanmıştır. Atıf sayılarının

\footnotetext{
12 Alt alanın haritası için: https://bit.ly/36bCcRD

${ }^{13}$ Alt alanın haritası için: https://bit.ly/2AITwBL

${ }^{14}$ Alt alanın haritası için: https://bit.ly/3e4p0jV
} 
konu kategorilerine dağglımı Şekil 5'te gösterilmiştir. Araştırma sonuçlarına göre, en çok atıf alan kategori 1112 atıf ile bibliyometri alanıdır. Yayın başına düşen atıf sayısının en yüksek olduğu kategori ise 43,4 atıf sayısı ile okuma alışkanlığı kategorisidir. Okuma alışkanlığını 18,5 atıf ortalaması ile bilgi profesyonellerinin eğitimi; 11,7 ile bilgi okuryazarlığı; 11,3 ile bibliyometri; 9,3 ile bilgi sistemleri; 7,9 ile etik; 7 ile belge yönetimi ve 6,4 ile kütüphane türleri konusu takip etmektedir. Makale başına düşen ortalama atıf sayısının en düşük olduğu alt kategori ise 5,6 ile kavramsal ve tarihsel çalışmalar konusudur.

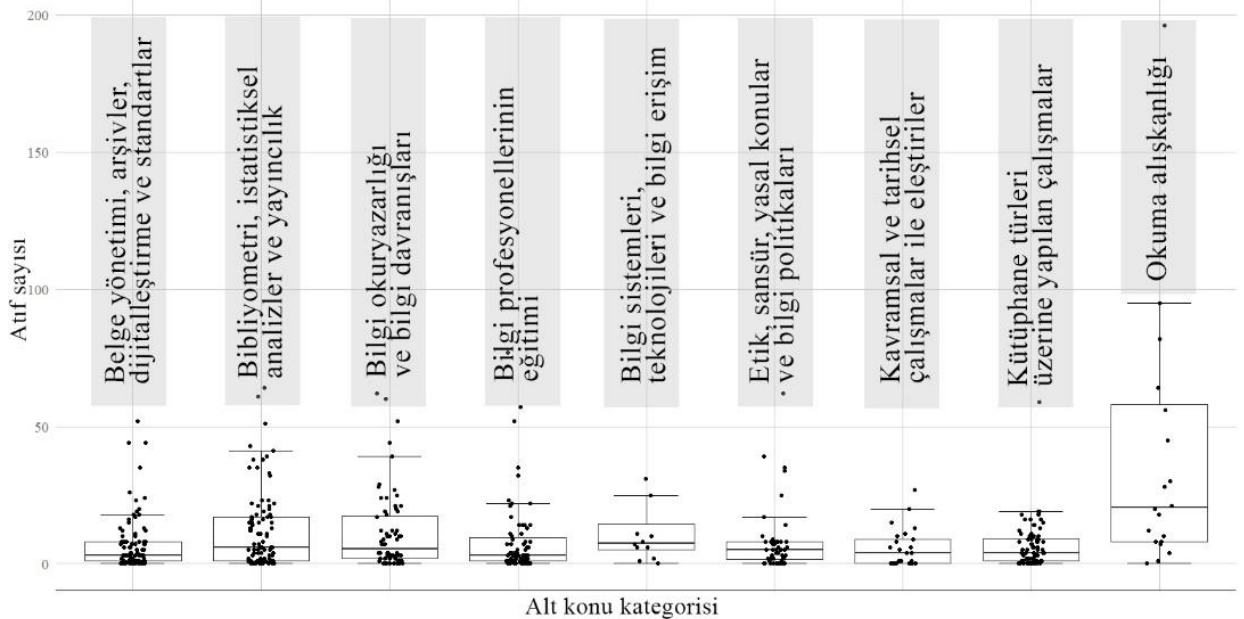

Şekil 5. Atıfların alt konu başlıklarına dağılımını gösterir grafik

Çalışılan konu kategorileri ile alınan atıf sayıları arasında anlamlı bir ilişki olup olmadığını saptamak üzere yapılan Kruskal-Wallis testi sonuçlarına göre alınan atıf sayılarında çalışılan konunun anlamlı bir etkisi olduğu anlaşılmıştır $(H=33,052, S D=8$, $p=0,000)$. Farklılığın hangi kategori ya da kategorilerden kaynaklandığını saptamak için ise Mann-Whitney U testi uygulanmıştır. Mann-Whitney U testi sonuçlarına göre okuma alışkanlığı ile diğer tüm kategoriler arasında anlamlı bir farklılık vardır. ${ }^{15}$ Diğer sınıflar

\footnotetext{
${ }^{15}$ Bibliyometri, istatistiksel analizler ve yayıncılık ile okuma alışkanlığı arasında: $U=508,000$, $p=0,001, Z=-3,271$

Bilgi okuryazarlığl ve bilgi davranışları ile okuma alışkanlığl arasında: $U=354,000, p=0,001, Z=-$ 3,253

Belge yönetimi, arşivler, dijitalleştirme ve standartlar ile okuma alışkanlığı arasında: $U=361,000$, $p=0,000, Z=-4,463$

Bilgi sistemleri, teknolojileri ve bilgi erişim ile okuma alışkanlığ arasında: $U=305,000, p=0,000$, $Z=-4,081$

Etik, sansür, yasal konular ve bilgi politikaları ile okuma alışkanlı̆̆ arasında: $U=182,500$, $p=0,000, Z=-3,954$

Kavramsal ve tarihsel çalışmalar ile okuma alışkanlığ $l$ arasında: $U=84,000, p=0,000, Z=-3,815$

Kütüphaneler ve kütüphane türleri üzerine yapılan çalışmalar ile okuma alışkanlığı arasında: $U=300,000, p=0,000, Z=-4,323$
} 
arasında anlamlı bir farklılık gözlenmemiştir. Bu durumda okuma alışkanlığı alanında yapılan çalışmaların diğer alanlarda yapılan çalışmalara göre atıf alma şansının daha yüksek olduğunu söylemek mümkündür.

\section{Alt Konu Kategorilerine Göre En Sik Atıf Yapılan Kaynak Türleri}

Türkiye'de yapılan kütüphanecilik ve bilgibilim araştırmalarında atıf yapılan kaynak türlerinin alt konulara göre değişiklik gösterip göstermediğini test etmek amacı ile $\chi^{2}$ testi uygulanmıştır. Test sonuçlarına göre makalenin dahil olduğu alt konu ile atıf yapılan kaynak türü arasında anlamlı bir ilişki vardır $\left(\chi_{(4)}^{2}=2176,645 ; p=0,000\right)$. Bu bağlamda, her bir alt kategorinin atıf yaptığı kaynak türlerinin bilinmesi önemlidir. Her bir alt kategorinin atıf yapmak için tercih ettiği kaynak türleri Şekil 6'da sunulmaktadır.

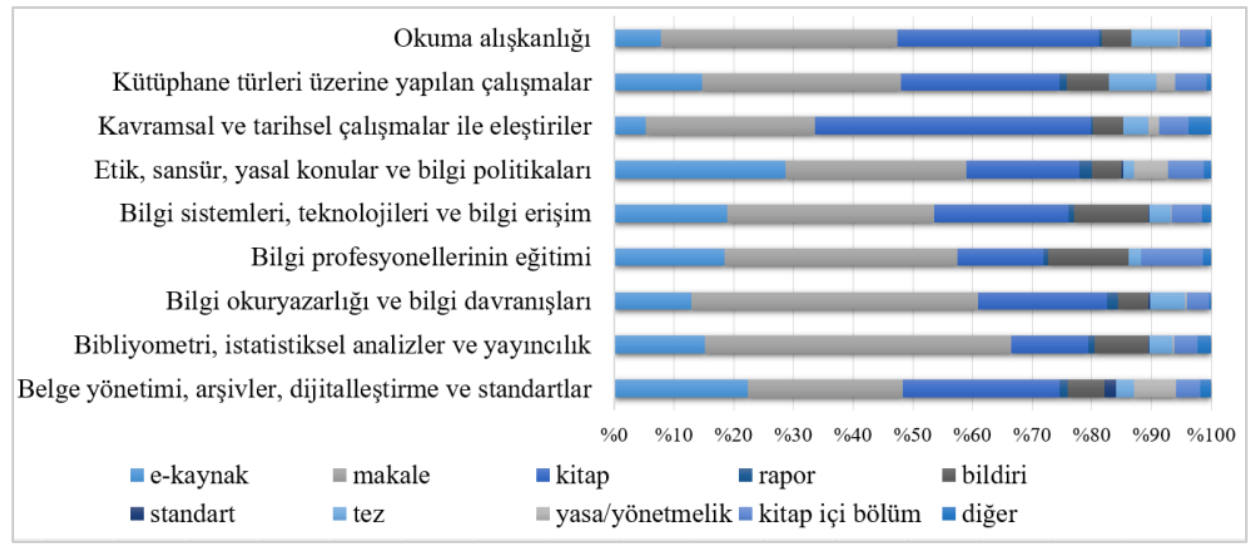

Şekil 6. En sık atıf yapılan kaynak türlerinin alt konu kategorilerine dağılımı

Şekil 6 detaylı olarak incelendiğinde elektronik kaynakların en sık kullanıldığı alt alanın etik kategorisi olduğu görülmüştür. Öte yandan elektronik kaynakları en az kullanan çalışmalar ise kavramsal ve tarihsel çalışmalardır. Bu alanda yapılan çalışmalarda sıklıkla kitaplardan faydalanılmaktadır. Bilimsel makalelerin tüm alt konu kategorilerinde sıklıkla kullanıldığı açıkça görülmektedir. Öte yandan yasa ve yönetmelikler hem etik hem de belge yönetimi kategorisi içinde önemli yeri olan kaynaklardır. Bildiriler bilgi sistemleri ve bilgi profesyonellerinin eğitimi kategorileri için önemli iken, tezler okuma alışkanlığı, kütüphane türleri ve bilgi okuryazarlığı alanlarında diğer alanlara göre daha yoğun kullanılmaktadır.

\section{Sonuç ve Öneriler}

Türkiye'de yayımlanmış kütüphanecilik ve bilgibilim konulu yayınların derinlemesine analizinin yapıldığı bu çalışmada sosyal ağ analizi sonucunda, ilgili alan için toplam dokuz alt konu kategorisi saptanmıştır. Bu dokuz alt alanın 2009 yılında Kütüphane ve Bilgibilim Ansiklopedisinin (Bates ve Maack, 2009) saptadığı ve giriş bölümünde sunulan sınıflar ile benzerlikler göstermesi Türkiye'de yürütülen çalışmaların dünya ile 
paralellik arz ettiğini kanıtlaması açısından önemlidir. Öte yandan alanımızda çalışılan konuların çeşitliliği alanın dinamik yapısını da ortaya koymaktadır.

Dokuz alt konu kategorisinde yapılan yayınlar için hangi dergilerin tercih edildiğine bakıldığında ise yayının konusu ile tercih edilen dergi arasında anlamlı bir ilişki olduğu, yani yazarların makalelerinin konusuna göre dergi seçtikleri gözlenmiştir. Bulgular değerlendirildiğinde kavramsal ve tarihsel çalışmalar ile eleştiriler (\%84), bilgi profesyonellerinin eğitimi (\%83), bibliyometri, istatistiksel analizler ve yayınc1lı (\%66), kütüphane türleri üzerine yapılan çalışmalar (\%66), bilgi sistemleri, teknolojileri ve bilgi erişim (\%57) ve okuma alışkanlığı üzerine yapılan çalışmalarda (\%55) sıklıkla Türk Kütüphaneciliği; etik, sansür, yasal konular ve bilgi politikaları (\%60) ve belge yönetimi, arşivler, dijitalleştirme ve standartlar (\%54) konularında ise Bilgi Dünyası'nın tercih edildiği görülmüştür. Bilgi okuryazarlığı ve bilgi davranışları konusunda yapılan yayınlar her iki dergide eşit derecede yer bulabilmiştir. Bu bulgular Türkiye'de kütüphanecilik ve bilgibilim dergilerinin konusal eğilimini göstermesi ve dergilerin güçlü ve zayıf yanlarını ortaya koyması açısından önemlidir. Türkçe literatürü oluşturan her iki derginin yayın profilinin ortaya çıkarılması ile hem yazarlara yayınlarını göndermeleri için yol gösterilmekte, hem de dergi kurullarına kendi literatürlerindeki boşlukları görmeleri konusunda fikir verilmektedir.

Öte yandan çalışma kapsamında yayın yapılan konu kategorisi ile alınan atıf sayısı arasında anlamlı bir ilişki olduğu da saptanmıştır. Bu bağlamda, okuma alışkanlığı alanında yapılacak bir yayının atıf alma ihtimali diğer tüm alt konu kategorilerinde yayımlanacak yayınlara göre daha fazladır. Ancak okuma alışkanlığı konusunda yayın sayısının oldukça az olduğu unutulmamalıdır. Veri sayısının azlığı doğru değerlendirme yapılmasına engel olabilir. Öte yandan bibliyometri konu alanındaki makaleler tüm atıfların \%20'ini almışlardır. Ancak makale başına düşen atıf sayısına bakıldı̆̆ında okuma alışkanlığının ilk sırada yer aldığı görülmektedir. Bu durum, az sayıda makalenin yayımlandığı okuma alışkanlığı kategorisinde yayımlanan makalelerin diğer tüm alanlarda yayımlanan makalelere göre daha fazla atıf alma potansiyeline sahip olduğunu göstermesi açısından önemlidir.

Son olarak, alt konu başlıklarına göre atıf yapmak üzere tercih edilen kaynakların, türlerine göre farklılık gösterip göstermediği test edildiğinde anlamlı bir farklılık saptanmıştır. Her bir alt konu kategorisinde atıf yapılan kaynak türünün farklılık gösterdiğinin ortaya koyulması bu kategorilerde çalışan kişilerin -özellikle genç araştırmacılar ve lisansüstü öğrencilerin- bilimsel araştırmalarına başlarken kaynak seçimi süreçlerinde rehberlik etmesi açısından önemlidir. Örneğin, belge yönetimi ve etik konusunda çalışan yazarlar için yasa ve yönetmelikler önemli bir yere sahipken diğer alt alanlarda yasa ve yönetmelik kullanımı bu denli yaygın değildir.

Çalışma sonucunda elde edilen bulgular kütüphanecilik ve bilgibilim alanında hizmet tasarımı ve alanın profilinin çıkarılmasının yanında etkili araştırma performans değerlendirmelerinin yapılabilmesi için de önemlidir. Özellikle farklı konu alanlarında var olan çeşitlilikler, ölçevlerin yanlış yorumlanması ile sonuçlanabilmektedir (Araştırma Değerlendirmesi üzerine..., 2019). Bu çalışma aracılığı ile çok geniş bir konu yelpazesine yayılmış makalelerin var olduğu kütüphanecilik ve bilgibilim alanının profili çıkarılmış ve her bir alanın atıf potansiyelleri ortaya koyulmuştur. Bulgulardan da açıkça görüldüğü üzere nispeten küçük bir alan olan kütüphanecilik ve bilgibilim alanında çok farklı yayın ve atıf pratikleri bulunmaktadır. $\mathrm{Bu}$ sebeple herkesin eşit varsayıldığı araştırma 
Kütüphanecilik ve Bilgibilim Araştırmalarının Alt Konu Alanlarına Dağılımı ve Alt Alanların Atıf Potansiyelleri Üzerine Bir Araştırma

performans değerlendirme sistemleri bazı alt alanlar için avantaj yaratırken bazıları için sayısal dezavantajlar getirebilmektedir. Hatalı kararlar alınmasının önüne geçebilmek için alanlar ve alt alanlar arasındaki farkılıkların bilinmesi, anlaşılması ve değerlendirmelerin bu farklılıklar göz önüne alınarak yapılması gereklidir.

\section{Kaynakça}

Åström, F. (2002). Visualizing library and information science concept spaces through keyword and citation based maps and clusters. CoLIS4 Proceedings of the Fourth International Conference on Conceptions of Library and Information Science (Yay. Haz. Bruce, H., Fidel, R., Ingwersen, P. ve Vakkari, P.) içinde (ss. 185-196). Colorado: Libraries Unlimited.

Al, U. (2008). Türkiye'nin bilimsel yayın politikası [Doktora Tezi]. Hacettepe Üniversitesi.

Araştırma Değerlendirmesi üzerine San Francisco Deklarasyonu. (2019). 13 Nisan 2019 tarihinde https://sfdora.org/read/tr/ adresinden erişildi.

Archambault, E. ve Gagné, E.V. (2004). Science-metrics final report: The use of bibliometrics in the social sciences and humanities. Social Sciences and Humanities Research Council of Canada (SSHRCC). 8 Nisan 2019 tarihinde http://www.sciencemetrix.com/pdf/SM_2004_008_SSHRC_Bibliometrics_Social_Science.pdf adresinden erişildi.

Atılgan, D., Atakan, C. ve Bulut, B. (2008). Türkçe kütüphanecilik dergilerinin atıf analizi. Türk Kütüphaneciliği, 22(4), 392-413. Erişim adresi: http://www.tk.org.tr/index.php/TK/article/view/541/534

Bates, M.J. ve Maack, M.N. (2009). Encyclopedia of library and information sciences (3. Bs.). Boca Raton: CRC Press.

Belter, C.W. (2015). Bibliometric indicators: Opportunities and limits. Journal of the Medical Library Association, 103(4), 219-221. Doi: 10.3163/1536-5050.103.4.014

Bitri, E. ve Keseroğlu, H.S. (2015). Türk Kütüphaneciliği ve Bilgi Dünyası dergilerinin özlerine eleştiren bir bakış. Türk Kütüphaneciliği, 29(1), 241-257. Erişim adresi: http://tk.org.tr/index.php/TK/article/view/2544/2544

ENRESSH (European Network for Research Evaluation in the Social Sciences and the Humanities). (2019). 8 Nisan 2019 tarihinde https://enressh.eu/about/ adresinden erişildi.

Fox, C. W., Paine, C. E. T. ve Sauterey, B. (2016). Citations increase with manuscript length, author number, and references cited in ecology journals. Ecology and Evolution, 6, 7717-7726. Doi: $10.1002 /$ ece 3.2505

Glänzel, W., Thijs, B., Schubert, A. ve Debackere, K. (2008). Subfield-specific normalized relative indicators and a new generation of relational charts: Methodological foundations illustrated on the assessment of institutional research performance. Scientometrics, 78(1), 165 188. Doi:10.1007/s11192-008-2109-5

Guthrie, S., Wamae, W., Diepeveen, S., Wooding S. ve Grant, J. (2013). Measuring research: A guide to research evaluation frameworks and tools. Santa Monica, CA: RAND Corporation. 9 Nisan 2019 tarihinde https://www.rand.org/content/dam/rand/pubs/monographs/MG1200/MG1217/RAND_MG1217. pdf adresinden erişildi.

Hjørland, B. (2018). Library and information science (LIS), part 1. Knowledge Organization, 45(3), 232-254. Doi: 10.5771/0943-7444-2018-3-232

Merton, R.K. (1968). The Matthew effect in science. Science, 159(3810), 56-63.

Doi: $10.1126 /$ science. 159.3810 .56 
Moed, H.F., Burger, W.J.M., Frankfort, J.G. ve Van Raan, A.F.J. (1985). The application of bibliometric indicators: Important field and time dependent factors to be considered. Scientometrics, 8(3-4), 177-203. Doi: 10.1007/BF02016935

Otte, E. ve Rousseau, R. (2002). Social network analysis: A powerful strategy, also for the information sciences. Journal of Information Science, 28(6), 441-453. Doi: 10.1177/016555150202800601

Polat, C., Akkaya, M.A. ve Binici, K. (2016). Türk Kütüphaneciliği dergisinin bilişsel ve entelektüel yapısına ilişkin bir analiz. Türk Kütüphaneciliği, 30(4), 664-677.

Simkin, M.V. ve Roychowdhury, V.P. (2003). Read before you cite!. Complex Systems, 14, 269274.

Taşkın, Z. ve Al, U. (2018). A content-based citation analysis study based on text categorization. Scientometrics, 114(1), 335-357. Doi: 10.1007/s11192-017-2560-2

Taşkın, Z., Doğan, G. ve Al, U. (2016). Sub-fields of library and information science in Turkey: A visualization study. Proceedings of the 21st International Conference on Science and Technology Indicators (Yay. Haz. Ismael Ràfols, Jordi Molas-Gallart, Elena Castro-Martínez, Richard Woolley) içinde (ss. 1494-1497). Valencia: Universitat Politècnica de València.

Tonta, Y. (1995). Türk Kütüphaneciliği'nde yeni atılımlar. Türk Kütüphaneciliği, 9(1), 3-4. Erişim adresi: http://www.tk.org.tr/index.php/TK/article/view/957/948

Tripathy, P. ve Tripathy, P. K. (2017). Fundamentals of research: A dissective view. Anchor Academic Publishing.

Uçak, N.Ö. (2008). Kütüphanecilik ve bilgi yönetimi literatüründe kullanıcı. Bilgi Dünyası, 9(1), 20-40. Erişim adresi: https://bd.org.tr/index.php/bd/article/view/326/323

Uçak, N.Ö. ve Al, U. (2009). The differences among disciplines in scholarly communication: A bibliometric analysis of theses. Libri, 59(3), 166-179. Doi: 10.1515/libr.2009.016

van der Zee, E. ve Vanneste, D. (2015). Tourism networks unravelled: A review of the literature on networks in tourism management studies. Tourism Management Perspectives, 15, 46-56. Doi: 10.1016/j.tmp.2015.03.006

van Eck, N.J. ve Waltman, L. (2011). Text mining and visualization using VOSviewer. ISSI Newsletter, 7(3), 50-54. 8 Nisan 2019 tarihinde https://arxiv.org/ftp/arxiv/papers/1109/1109.2058.pdf adresinden erişildi.

van Eck, N.J. ve Waltman, L. (2019). VOSviewer manual: manual for VOSviewer version 1.6.11. 10 Nisan 2019 tarihinde http://www.vosviewer.com/download/f-13s2.pdf adresinden erişildi.

Wilson, J. ve diğerleri. (2015). The metric tide: Report of the independent review of the role of metrics in research assessment and management. Londra: HEFCE. Doi: 10.13140/RG.2.1.4929.1363

Zhu, Y. ve Yan, E. (2015). Dynamic subfield analysis of disciplines: An examination of the trading impact and knowledge diffusion patterns of computer science. Scientometrics, 104(1), 335-359. Doi: 10.1007/s11192-015-1594-6 